\title{
The efficacy of molecular subtyping in predicting postoperative recurrence in breast-conserving therapy: a 15-study meta-analysis
}

Jing Chen ${ }^{1+}$, Peng Jiang ${ }^{1+}$, Han-jin Wang ${ }^{1}$, Jia-yi Zhang ${ }^{2}$, Yang Xu², Mu-hong Guo ${ }^{1}$, Bin Zhang ${ }^{1}$, Chong-yin Tang ${ }^{1}$, Hong-yong $\mathrm{CaO}^{3}$ and Shui Wang ${ }^{4^{*}}$

\begin{abstract}
Background: Recent research displays that breast cancer (BC) is a heterogeneous disease and distinct molecular subtypes yield different prognostic outcomes.

Methods: We conducted a meta-analysis to clarify the role of molecular subtypes in recurrence risk after breast-conserving therapy (BCT). Eligible studies of single- (ER, PR, Her-2, and p53) and triple-molecular (Luminal A, Luminal B, Her-2, triple-negative) subtypes were identified through multiple search strategies. Pooled hazard ratios with $95 \%$ confidence intervals were calculated to assess this research topic.

Results: Fifteen studies involving 21,645 participants were included in the meta-analysis. Her-2 positive patients had a significantly higher recurrence risk in both overall merge ( $H R=1.97,95 \% \mathrm{Cl}: 1.41-2.75)$ and subtotal merge of local recurrence $(\mathrm{LR})(\mathrm{HR}=1.93,95 \% \mathrm{Cl}: 1.34-2.78)$. Significantly higher risk of recurrence was also observed in p53 positive patients by overall merge ( $\mathrm{HR}=1.78,95 \% \mathrm{Cl}: 1.49-2.12)$ and subtotal merge of $\mathrm{LR}(\mathrm{HR}=1.73,95 \% \mathrm{Cl}$ : 1.44-2.07). When setting Luminal A as a baseline, Luminal B, Her-2, and triple-negative all showed significantly increased risk for both $L R$ and distant recurrence (DR). Comparing triple-negative and non-triple-negative subtypes showed the biggest risk for overall recurrence ( $H R=3.19,95 \% \mathrm{Cl}: 1.91-5.31)$ and $L R(H R=3.31,95 \% \mathrm{Cl}: 1.69-6.45)$.

Conclusions: Our meta-analysis showed significant differences in recurrence risk among various molecular subtypes after BCT. Although Her-2 and p53 positive subtypes can be considered independent prognostic biomarkers for indicating high LR risk, triple-molecular biomarkers showed higher clinical value. Triple-negative subtype showed the highest recurrence risk among all subtypes, and adjuvant chemotherapy should be considered for it.
\end{abstract}

Keywords: Breast cancer, Molecular subtypes, Breast-conserving therapy, Recurrence, Meta-analysis

\section{Background}

Breast-conserving therapy $(\mathrm{BCT})$ is considered the standard treatment for early-stage breast cancer (BC) [1-3]. Though patients who undergo breast-conserving surgery (BCS) have a better quality of life and equivalent survival compared with those undergoing mastectomy [3], many randomized trials consistently demonstrate a measurable increased risk of local recurrence (LR) after BCS

\footnotetext{
* Correspondence: ws0801@hotmail.com

${ }^{\dagger}$ Equal contributors

${ }^{4}$ Department of Breast Surgery, First Affiliated Hospital of Nanjing Medical University, Nanjing, China

Full list of author information is available at the end of the article
}

when compared to mastectomy [4-6], estimated at $1 \%$ per year [3,7-10].

The factors affecting recurrence are complex, including clinical and histological characteristics, with or without postoperative adjuvant radiotherapy and systemic therapy (chemotherapy and/or hormone therapy) [11]. Recent researches display that $\mathrm{BC}$ is a heterogeneous disease [12] and distinct molecular subtypes yield different prognostic outcomes [13-19]. These molecular markers mainly include estrogen receptor (ER), progesterone receptor (PR), human epidermal growth factor receptor 2 (HER-2), p53, and Ki67 [14,20]; these have immensely contributed to the selection of the optimal strategy for BCT [21-23]. However, the impact of molecular subtypes on LR or distant 
recurrence (DR) has not been systemically evaluated. Therefore, we conducted a meta-analysis to clarify the role of molecular subtypes in $\mathrm{BC}$ recurrence after $\mathrm{BCT}$.

\section{Methods}

\section{Search strategy}

Original articles analyzing the hazard ratio (HR) of recurrence after $\mathrm{BCT}$ in different $\mathrm{BC}$ molecular subtypes were searched by online databases PubMed, Embase, and Web of Science. We selected studies carefully by the following sets of key words variably combined: 'breast cancer', 'breast-conserving surgery', 'breast-conserving therapy', 'recurrence', 'hazard ratio', 'molecular marker', and 'molecular subtype'; the last search update was performed on 10 January 2014. All eligible studies published in English were reviewed, and their bibliographies were also examined for other relevant publications. Relevant review articles were manually searched to find additional eligible studies. If more than one article was published using the same series of study subjects, we only chose the latest or most complete study for this meta-analysis. All the studies enrolled in this meta-analysis have been performed with the approval of an appropriate ethics committee. Researches carried out on humans are all in compliance with the Helsinki Declaration.

\section{Inclusion and exclusion criteria}

We followed the guidelines of the critical checklist proposed by the Dutch Cochrane Centre Meta-analysis of
Observational Studies in Epidemiology (MOOSE) [24]. Articles were identified as eligible when they fit the following criteria: (1) they performed BCS on BC patients; (2) they focused on postoperative recurrence; (3) they investigated the association between recurrence and different BC molecular subtypes. Altogether, 953 studies were excluded by exclusion criteria and further quality evaluation that are presented in Figure 1.

\section{Data extraction}

All data were carefully extracted from eligible publications in duplicate by two co-authors (PJ and JZ). Any disagreements were resolved by discussion between the two authors. The extracted data elements in Table 1 include the followings: first author's last name, publication year, case nationality, dominant ethnicity, study design, number of cases, median time to follow-up, percentage of patients who received adjuvant radiotherapy (RT), percentage of patients who received adjuvant systemic therapy (AST), types of recurrence, source of HR, and characteristics of enrolled cases.

The extracted data elements in Table 2 show the HRs and $95 \%$ confidence intervals (CIs) of different recurrences among molecular subtypes. If $\mathrm{HR}$ was not reported directly, data were extracted from Kaplan-Meier curves of survival outcomes to extrapolate required data using the previously described methods [25-27]. We also wrote emails to the corresponding authors of enrolled

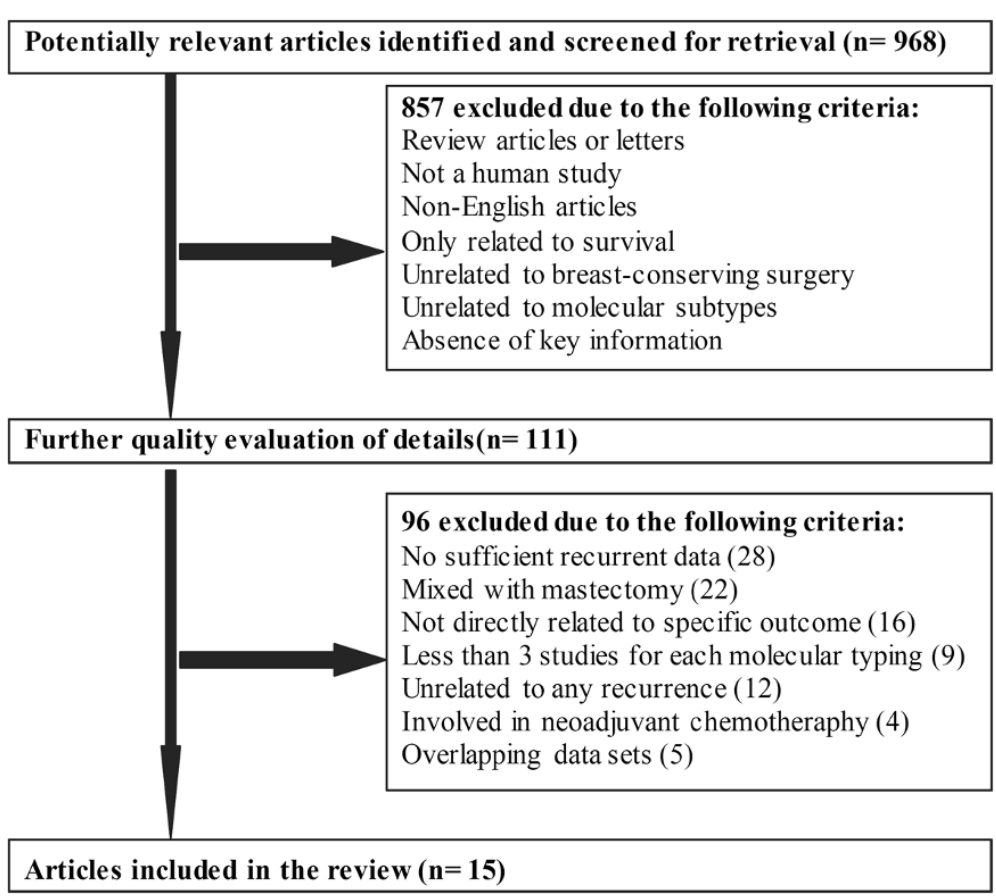

Figure 1 Flow diagram of study selection process. 
Table 1 Main characteristics of the studies enrolled in the meta-analysis

\begin{tabular}{|c|c|c|c|c|c|c|c|c|c|c|c|}
\hline \multirow{2}{*}{$\begin{array}{l}\text { First author and } \\
\text { publishing year }\end{array}$} & \multirow{2}{*}{$\begin{array}{l}\text { Case } \\
\text { nationality }\end{array}$} & \multirow{2}{*}{$\begin{array}{l}\text { Dominant } \\
\text { ethnicity }\end{array}$} & \multirow{2}{*}{$\begin{array}{l}\text { Study } \\
\text { design }\end{array}$} & \multirow{2}{*}{$\begin{array}{l}\text { Case } \\
\text { number }\end{array}$} & \multirow{2}{*}{$\begin{array}{l}\text { Follow-up } \\
\text { median }(\mathrm{m})\end{array}$} & \multirow{2}{*}{$\begin{array}{l}\text { RT } \\
\text { (\%) }\end{array}$} & \multicolumn{2}{|c|}{ AST (\%) } & \multirow{2}{*}{$\begin{array}{l}\text { Types of } \\
\text { recurrence }\end{array}$} & \multirow{2}{*}{$\begin{array}{l}\text { Source } \\
\text { of HR }\end{array}$} & \multirow{2}{*}{$\begin{array}{l}\text { Characteristics of } \\
\text { enrolled cases }\end{array}$} \\
\hline & & & & & & & $\overline{\mathrm{HT}}$ & CT & & & \\
\hline Hattangadi [30] & USA & Caucasian & $\mathrm{R}$ & 1,223 & 70 & 100 & 77.0 & 46.0 & TR & Reported & IBC, pT1-2 No-3 \\
\hline Zauls [31] & USA & Caucasian & $P$ & 459 & 45 & 100 & Total & 62.1 & LF & $\mathrm{DE}$ & $\begin{array}{l}\text { DCIS or IBC, tumor size } \\
\leq 3 \mathrm{~cm} \text {, positive } \mathrm{LNs} \leq 3\end{array}$ \\
\hline Han [32] & Canada & Caucasian & $\mathrm{R}$ & 180 & 104.4 & 30.6 & NM & NM & $L R$ & Reported & $\begin{array}{l}\text { DCIS with or without } \\
\text { microinvasion }\end{array}$ \\
\hline Millar [33] & Australia & Caucasian & P & 498 & 64 & 100 & 49.0 & 38.0 & LRR/IBTR/DM & $\mathrm{DE}$ & $\mathrm{IBC}$ \\
\hline Moran [34] & USA & Caucasian & $\mathrm{R}$ & 368 & 78 & 100 & 49.0 & 36.0 & $L R$ & DE & $\begin{array}{l}\text { IBC, stage I-II, LN (+), } \\
\text { margin (-) }\end{array}$ \\
\hline Wong [35] & Singapore & Asian & $\mathrm{R}$ & 541 & 72 & 100 & 68.0 & 36.0 & LR/DM & Reported & $\mathrm{IBC}, \mathrm{LN}(-)$ \\
\hline Kim [36] & Korea & Asian & P & 1,589 & 61 & 100 & 71.8 & 66.4 & IBTR & Reported & $\begin{array}{l}\text { IBC, tumor size } \leq 5 \mathrm{~cm} \text {, } \\
\text { age }>40 \text { years }\end{array}$ \\
\hline Bantema [37] & Netherlands & Caucasian & $\mathrm{R}$ & 752 & 41 & 100 & 38.7 & 35.4 & LR/DM & Reported & |BC, stages |-I|| \\
\hline Arvold [38] & USA & Caucasian & $\mathrm{R}$ & 1,434 & 85 & 100 & Total & 91.0 & $L R$ & Reported & |BC, stage I-|| \\
\hline Truong [39] & Canada & Caucasian & $\mathrm{R}$ & 5,688 & 71.7 & 100 & 36.6 & 26.7 & LR/RR/LRR & Reported & $\begin{array}{l}\text { IBC, pT1-2, positive } \\
\text { LNs } \leq 3, \mathrm{M} 0\end{array}$ \\
\hline Sharon [40] & Canada & Caucasian & $\mathrm{R}$ & 133 & 107 & 0.0 & NM & NM & $L R$ & Reported & DCIS, margin (-) \\
\hline Roos [41] & Netherlands & Caucasian & $\mathrm{R}$ & 39 & 39 & 51.3 & 0.0 & NM & $L R$ & $\mathrm{DE}$ & DCIS \\
\hline Yau [42] & China & Asian & $\mathrm{R}$ & 605 & 64.8 & 100 & 74.0 & 45.0 & IBTR/DF & Reported & $\mathrm{IBC}, \mathrm{T} 1-2$ \\
\hline Smith [43] & USA & Caucasian & $\mathrm{R}$ & 8,724 & 60 & 73.0 & NM & 3.0 & SIBC & Reported & $\begin{array}{l}\text { IBC, age } \geq 70 \text { years, } \\
\text { tumor size } \leq 2 \mathrm{~cm}, L N(-)\end{array}$ \\
\hline Silvestrini [44] & Spain & Caucasian & $\mathrm{R}$ & 635 & 72 & 78.1 & 0.0 & 0.0 & LR & Reported & $\begin{array}{l}\text { Resectable breast } \\
\text { cancer, N0, MO }\end{array}$ \\
\hline
\end{tabular}

Study design is described as either prospective $(\mathrm{P})$ or retrospective $(\mathrm{R})$.

Radiotherapy (RT) is defined as accelerated partial breast irradiation (APBI), whole breast irradiation (WBI) or MammoSite brachytherapy (MB).

Adjuvant systemic therapy (AST) is defined as hormone/endocrine therapy (HT) only, chemotherapy (CT) only, or both.

Abbreviations: $m$ month $H R$ hazard ratio, $N M$ not mentioned, $T R$ true recurrence, $L F$ local failure, $L R$ local recurrence or relapse, $L R R$ locoregional recurrence; $I B T R$ ipsilateral breast tumor recurrence, $D M$ distant metastasis, $R R$ regional recurrence, $D F$ distant failure, $S I B C$ second ipsilateral breast cancer, $D E$ dataextrapolated $I B C$ invasive breast cancer, DCIS ductal carcinoma in situ, LN lymph node.

studies to obtain additional information and original data needed for the meta-analysis.

\section{Statistical analysis}

All statistical analyses were conducted using Stata (version 11.0; StataCorp LP, College Station, TX, USA) and Excel (version 2007; Microsoft Corp., WA, USA). The aggregation of HRs and 95\% CIs were calculated following Tierney's method [27]. Forrest plots were used to estimate the effect of different molecular subtypes on recurrence after BCT. The heterogeneity assumption of pooled HRs was verified by Cochran's Q-test, and the percentage of Higgins' I-squared statistic $\left(\mathrm{I}^{2}\right)$ was used to quantify the extent of heterogeneity explained by these characteristics of enrolled studies. If significant heterogeneity was observed $\left(P<0.1\right.$ or $\left.\mathrm{I}^{2}>50 \%\right)$, a random-effects model (Der Simonian- Laird method) was applied; otherwise, the fixed-effects model (MantelHaenszel method) was adopted [28]. Potential publication bias was determined by Egger's linear regression test with a funnel plot [29].
To avoid the influence of heterogeneity among these studies, we also conducted a subgroup analysis stratified by different recurrence categories (LR and DR). We defined LR to include true recurrence, local failure, local recurrence or relapse, ipsilateral breast tumor recurrence, locoregional recurrence, and second ipsilateral BC. DR was defined as distant metastasis or failure, and recurrence was defined as any of $L R$ and/or DR, the merger of LR and DR in the same study or not definitely mentioned. All $P$ values were two-sided and a $P$ value less than 0.05 was considered to be statistically significant.

\section{Results}

\section{Summary of included studies}

Fifteen studies involving 21,645 participants finally met the inclusion criteria [30-44]. The main features of eligible studies are summarized in Table 1. These studies collect data from the United States, Canada, Australia, Singapore, Korea, the Netherlands, China, and Spain. The dominant ethnicity of 13 enrolled studies is Caucasian [30-34,37-41,43,44], with only three studies executed in Asians $[35,36,42]$. Most enrolled studies are retrospective 
Table $2 \mathrm{HRs}$ and $95 \% \mathrm{Cls}$ of various comparisons between molecular subtypes of breast cancer stratified by recurrence types

\begin{tabular}{|c|c|c|c|c|c|c|c|c|c|}
\hline $\begin{array}{l}\text { First author and } \\
\text { publishing year }\end{array}$ & $\begin{array}{l}\text { Types of } \\
\text { recurrence }\end{array}$ & $\begin{array}{l}\text { LB vs. LA } \\
\text { HR }(95 \% \text { Cl) }\end{array}$ & $\begin{array}{l}\text { Her-2 vs. LA } \\
\text { HR }(95 \% \mathrm{Cl})\end{array}$ & $\begin{array}{l}\text { TN vs. LA } \\
\text { HR (95\% Cl) }\end{array}$ & $\begin{array}{l}\text { TN vs. non-TN } \\
\text { HR }(95 \% \mathrm{CI})\end{array}$ & $\begin{array}{l}\text { ER - vs. + } \\
\text { HR }(95 \% \mathrm{Cl})\end{array}$ & $\begin{array}{l}\text { PR - vs. + } \\
\text { HR (95\% Cl) }\end{array}$ & $\begin{array}{l}\text { Her-2 + vs. - } \\
\text { HR }(95 \% \mathrm{Cl})\end{array}$ & $\begin{array}{l}\text { p53 + vs. - } \\
\text { HR (95\% Cl) }\end{array}$ \\
\hline Hattangadi [30] & TR & NM & NM & NM & $4.80(1.40,15.80)^{\mathrm{M}}$ & NM & NM & NM & NM \\
\hline Zauls [31] & LF & NM & NM & NM & NM & $0.75(0.15,3.85)^{\cup}$ & $0.55(0.12,2.44)^{\cup}$ & $0.64(0.07,5.88)^{\cup}$ & NM \\
\hline Han [32] & $L R$ & $1.90(0.90,4.00)^{\cup}$ & $1.90(0.90,3.80)^{\cup}$ & $0.60(0.10,2.40)^{U, D E}$ & NM & $0.87(0.48,1.58)^{\cup}$ & $1.09(0.61,1.98)^{\cup, D E}$ & $1.98(1.11,3.53)^{\mathrm{M}, \mathrm{DE}}$ & NM \\
\hline Millar [33] & $L R$ & $2.48(0.98,6.29)^{\mathrm{M}}$ & $1.93(0.38,9.75)^{\mathrm{M}}$ & $3.94(1.28,12.11)^{\mathrm{M}}$ & NM & NM & NM & NM & $1.20(0.57,2.55)^{\mathrm{U}, \mathrm{DE}}$ \\
\hline Millar [33] & DM & $2.87(1.33,6.22)^{\mathrm{M}}$ & $1.83(0.39,8.64)^{\mathrm{M}}$ & $3.27(1.14,9.40)^{\mathrm{M}}$ & NM & NM & NM & NM & $2.57(1.30,5.06)^{\mathrm{U}}$ \\
\hline Millar [33] & $L R+D M$ & $2.71(1.49,4.90)^{\mathrm{M}, \mathrm{DE}}$ & $1.88(0.61,5.76)^{\mathrm{M}, \mathrm{DE}}$ & $3.89(2.03,7.44)^{\mathrm{M}, \mathrm{DE}}$ & NM & NM & NM & NM & $1.83(1.10,3.02)^{U, D E}$ \\
\hline Moran [34] & $L R$ & NM & NM & NM & $2.21(0.63,7.81)^{\mathrm{M}}$ & NM & NM & $1.22(0.30,4.93)^{\mathrm{M}}$ & NM \\
\hline Bantema [34] & $L R R+D M$ & NM & NM & NM & $3.03(1.37,6.67)^{\mathrm{M}}$ & NM & NM & NM & NM \\
\hline Wong [35] & $L R$ & NM & NM & NM & $3.30(1.20,9.60)^{\mathrm{U}}$ & NM & NM & NM & NM \\
\hline Wong [35] & DM & $3.60(1.10,11.30)^{\cup}$ & $6.00(1.60,22.60)^{U}$ & $4.20(1.10,16.00)^{\cup}$ & NM & NM & NM & NM & NM \\
\hline Wong [35] & $L R+D M$ & $2.16(0.85,5.50)^{\mathrm{M}}$ & $2.22(1.08,9.84)^{\mathrm{M}}$ & $3.48(1.22,9.93)^{\mathrm{M}}$ & NM & NM & NM & NM & NM \\
\hline Kim [36] & IBTR & $1.55(0.32,7.51)^{\mathrm{M}}$ & $0.55(0.05,6.34)^{\mathrm{M}}$ & $1.17(0.22,6.26)^{\mathrm{M}}$ & NM & NM & NM & NM & NM \\
\hline Arvold [38] & $L R$ & $2.10(0.95,4.80)^{\mathrm{M}}$ & $5.20(1.80,15.00)^{\mathrm{M}}$ & $3.90(1.70,9.00)^{\mathrm{M}}$ & NM & NM & NM & NM & NM \\
\hline Truong [39] & LRR & NM & NM & NM & NM & $1.29(0.99,1.69)^{\mathrm{M}}$ & NM & NM & NM \\
\hline Sharon [40] & $L R$ & NM & NM & NM & NM & NM & NM & $1.93(1.02,3.65)^{\mathrm{M}}$ & NM \\
\hline Roos [41] & $L R$ & NM & NM & NM & NM & $2.50(0.42,10.00)^{\mathrm{U}, \mathrm{DE}}$ & $1.11(0.24,5.00)^{U, D E}$ & $3.90(0.80,20.10)^{\cup}$ & $4.00(0.90,18.10)^{\cup}$ \\
\hline Yau [42] & IBTR & NM & NM & NM & NM & NM & NM & $2.19(0.76,6.35)^{\cup}$ & NM \\
\hline Yau [42] & DF & NM & NM & NM & NM & NM & NM & $2.17(0.99,4.75)^{\cup}$ & NM \\
\hline Yau [42] & $\mathrm{IBTR}+\mathrm{DF}$ & NM & NM & NM & NM & NM & NM & $1.57(1.26,1.97)^{\mathrm{U}, \mathrm{DE}}$ & NM \\
\hline Smith [43] & $\mathrm{SIBC}$ & NM & NM & NM & NM & NM & $1.49(1.00,2.22)^{\cup}$ & NM & NM \\
\hline Silvestrini [44] & $L R$ & NM & NM & NM & NM & $1.12(0.42,2.97)^{\mathrm{U}, \mathrm{DE}}$ & NM & NM & $1.75(1.44,2.11)^{\mathrm{U}, \mathrm{DE}}$ \\
\hline
\end{tabular}

The source of HRs and $95 \% \mathrm{Cls}$ is derived from univariate analysis $\left({ }^{(}\right)$, multivariate analysis $\left({ }^{\mathrm{M}}\right)$ or data-extrapolated $(\mathrm{DE})$.

$\mathrm{Cl}$, confidence interval; DE, data-extrapolated; DF, distant failure; DM, distant metastasis; ER, estrogen receptor; Her-2, human epidermal growth factor receptor 2; HR, hazard ratio; IBTR, ipsilateral breast tumor recurrence; LA, Luminal A; LB, Luminal B; LF, local failure; LR, local recurrence or relapse; LRR, locoregional recurrence; NM, not mentioned; PR, progesterone receptor; SIBC, second ipsilateral breast cancer; $\mathrm{TN}$, triple-negative; TR, true recurrence. 
in design [30,32,34,35,37-44], except three prospective studies $[31,33,36]$. The median time to follow-up is in the range of 39 to 107 months.

A total of 20,890 patients $(88.3 \%)$ received postoperative radiotherapy (RT), including accelerated partial breast irradiation, whole breast irradiation, or MammoSite brachytherapy. Adjuvant systemic therapy (AST) after BCS are defined as hormone/endocrine therapy (HT) only, chemotherapy (CT) only, or both. The directly reported rates range from $0.0 \%$ to $77.0 \%$ for $\mathrm{HT}$ and $0.0 \%$ to $66.4 \%$ for $\mathrm{CT}$. Excluding studies that did not mention the respective rates of HT or CT, 6,288 patients (49.4\%) underwent HT and 4,817 patients $(22.5 \%)$ accepted CT (Table 1$)$.

\section{Single-molecular subtypes and postoperative recurrence}

Single-molecular subtypes are defined as the dichotomous status of a single receptor or protein, which will be excluded from the meta-analysis if less than three studies are found involved in. Altogether, four proteins (ER, PR, Her-2, and p53) are included in analyses.

Six articles involved Her-2 typing [31,32,34,40-42] (Figure $2 \mathrm{C}$ ) and we found that Her-2 positive patients had a significantly higher recurrence risk when compared to Her-2 negative individuals in both overall merge $(\mathrm{HR}=$ 1.97, 95\% CI: 1.41-2.75) and LR subtotal merge (HR = 1.93, 95\% CI: 1.34-2.78). A significantly higher risk of postoperative recurrence is also observed in p53 positive patients by overall merge (HR $=1.78,95 \%$ CI: $1.49-2.12)$ and LR subtotal merge (HR $=1.73,95 \% \mathrm{CI}$ : $1.44-2.07)$ in three studies $[33,41,44]$ (Figure 2D). Five studies focus on ER typing $[31,32,39,41,44]$, and no significant correlation is found between ER typing and LR (HR $=1.21,95 \% \mathrm{CI}$ : 0.96-1.53) (Figure 2A). Similarly, four eligible studies involving PR typing $[31,32,41,43]$ did not show a significant result $(\mathrm{HR}=1.29,95 \% \mathrm{CI}$ : 0.94-1.76) (Figure 2B). Above pooled HRs and $95 \%$ Cls are calculated by the fixed-effects model (Table 3).

\section{Triple-molecular subtypes and postoperative recurrence}

Triple-molecular subtypes are defined as the combination of dichotomous status of three receptors (ER, PR, and Her-2), including Luminal A (ER + and/or PR + and Her-2-), Luminal B (ER + and/or PR + and Her-2+), Her-2 (ER- and PR- and Her-2+), and triple-negative (ER- and PR- and Her-2-) [45].

By setting Luminal A as a baseline, the recurrence risk of patients with Luminal B, Her-2, or triple-negative subtypes are compared by overall and subtotal merge of five studies $[32,33,35,36,38]$ (Table 2). We found that individuals with Luminal $\mathrm{B}$ had a significantly higher risk for total recurrence $(\mathrm{HR}=2.23,95 \% \mathrm{CI}$ : $1.55-3.19)$, LR $(\mathrm{HR}=2.05,95 \% \mathrm{CI}: 1.31-3.23)$ or $\mathrm{DR}(\mathrm{HR}=3.08,95 \%$ CI: 1.62-5.86) (Figure 3A). This significantly higher risk is also observed in patients with Her-2 subtype by overall merge $(\mathrm{HR}=2.26,95 \% \mathrm{CI}: 1.42-3.60)$, LR subtotal merge $(\mathrm{HR}=2.33,95 \% \mathrm{CI}: 1.35-4.02)$, and DR subtotal merge $(\mathrm{HR}=3.64,95 \% \mathrm{CI}: 1.33-9.97)$ (Figure 3B). Triple-negative individuals also had significantly higher risk of overall recurrence ( $\mathrm{HR}=2.90,95 \% \mathrm{CI}: 1.84-4.58)$, LR (HR $=2.64,95 \%$ CI: 1.48-4.71), and DR $(\mathrm{HR}=3.60$, 95\% CI: 1.57-8.25) (Figure 3C). Four studies focus on the comparison between triple-negative and non-triplenegative subtypes $[30,34,35,37]$, and a significantly higher recurrence risk is observed in patients with triple-negative subtype by overall merge $(\mathrm{HR}=3.19,95 \% \mathrm{CI}: 1.91-5.31)$ and LR subtotal merge $(\mathrm{HR}=3.31,95 \% \mathrm{CI}: 1.69-6.45)$

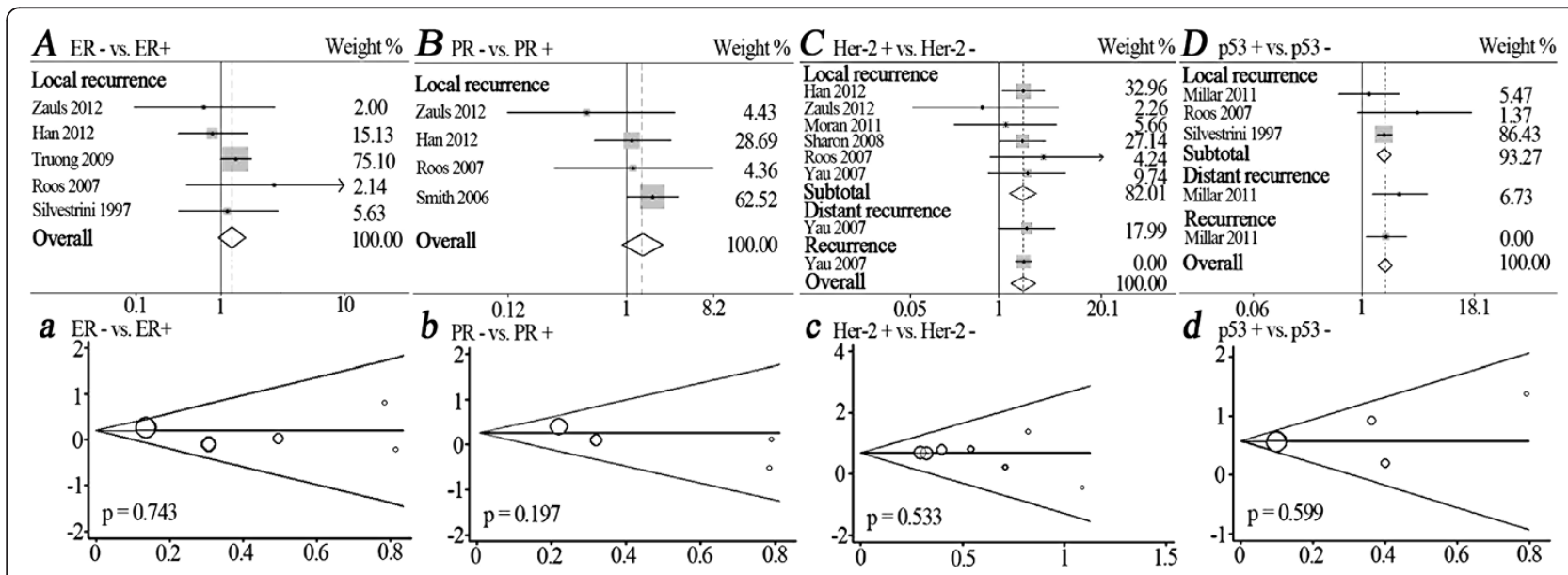

Figure 2 Forest plots for recurrence risk of single-molecular typing after BCT in the following comparisons: ER - vs. ER+ (A), PR - vs. PR+ (B), Her-2+ vs. Her-2 - (C) and p53+ vs. p53- (D). Squares and horizontal lines correspond to the study-specific HRs and 95\% Cls, respectively. The area of the squares correlates the weight and the diamonds represent the summary HRs and 95\% Cls. Begg's funnel plots for publication bias for the following comparisons: ER - vs. ER+ (a), PR - vs. PR+ (b), Her-2+ vs. Her-2 - (c) and p53+ vs. p53- (d). ER, estrogen receptor; PR, progesterone receptor; Her-2, human epidermal growth factor receptor 2. 
Table 3 Pooled HRs, $95 \%$ Cis, and $P$ values of different dichotomous status of single receptor or protein stratified by recurrence types

\begin{tabular}{|c|c|c|c|c|c|c|c|c|c|c|c|c|}
\hline \multirow{2}{*}{$\begin{array}{l}\text { Types of } \\
\text { recurrence }\end{array}$} & \multicolumn{3}{|c|}{ ER - vs. + } & \multicolumn{3}{|c|}{ PR - vs. + } & \multicolumn{3}{|c|}{ Her-2 + vs. - } & \multicolumn{3}{|c|}{ p53 + vs. - } \\
\hline & $\mathrm{N}$ & HR $(95 \% \mathrm{Cl})$ & $P$ & $\mathrm{~N}$ & HR $(95 \% \mathrm{Cl})$ & $P$ & $\mathrm{~N}$ & HR $(95 \% \mathrm{Cl})$ & $P$ & $\mathrm{~N}$ & HR (95\% Cl) & $P$ \\
\hline Overall & 5 & $1.21(0.96,1.53)^{\mathrm{a}}$ & 0.107 & 4 & $1.29(0.94,1.76)^{a}$ & 0.118 & 7 & $1.97(1.41,2.75)^{a}$ & $<0.01$ & 4 & $1.78(1.49,2.12)^{a}$ & $<0.01$ \\
\hline Local recurrence & 5 & $1.21(0.96,1.53)^{\mathrm{a}}$ & 0.107 & 4 & $1.29(0.94,1.76)^{\mathrm{a}}$ & 0.118 & 6 & $1.93(1.34,2.78)^{a}$ & $<0.01$ & 3 & $1.73(1.44,2.07)^{\mathrm{a}}$ & $<0.01$ \\
\hline Distant recurrence & 0 & - & - & 0 & - & - & 1 & $2.17(0.99,4.75)$ & - & 1 & $2.57(1.30,5.06)$ & - \\
\hline Recurrence & 0 & - & - & 0 & - & - & 1 & $1.57(1.26,1.97)$ & - & 1 & $1.83(1.10,3.02)$ & - \\
\hline
\end{tabular}

Local recurrence is defined to include true recurrence (TR), local failure (LF), local recurrence or relapse (LR), ipsilateral breast tumor recurrence (IBTR), locoregional recurrence (LRR), or second ipsilateral breast cancer (SIBC). Distant recurrence is defined to include distant metastasis (DM) or distant failure (DF). Recurrence is defined to include any local and/or distant recurrence, which is the merge of LR and DR in the same study or not definitely mentioned.

${ }^{a}$ The HRs and $95 \%$ Cls of enrolled studies are pooled by the fixed-effects model.

$\mathrm{Cl}$, confidence interval; ER, estrogen receptor; Her-2, human epidermal growth factor receptor 2; HR, hazard ratio; N, number of studies; PR, progesterone receptor.

(Figure 3D). Above pooled HRs and 95\% CIs are calculated by the fixed-effects model (Table 4).

\section{Publication bias}

Unexpectedly, the comparison of TN vs. LA (Figure 3c) shows obvious publication bias by Egger's test $(P=0.021)$. However in the other seven molecular typing comparisons, the shapes of funnel plots seem symmetrical and the results of Egger's test do not suggest any publication bias (all $P>0.05$ ) (Figure 2a, b, c, d and Figure 3a, b, d).

\section{Discussion}

$\mathrm{BC}$ has become a major cause of morbidity and mortality in women [46]; there are an estimated 5.2 million BC survivors worldwide [47]. A recent study reported that the incidence of BC in the United States from 2000 to 2009 showed a recent increase, especially for early-stage disease (in situ and localized) in non-Hispanic blacks and Asian/Pacific Islanders [48]. In addition, from 1976 to 2009, the incidence of advanced BC rose significantly among young women in the US (from 1.53/100,000 to 2.9/100,000); this trend may be accelerating and seems confined to women aged 25 to 39 years [49].

Currently, local excision combined with adjuvant RT has been well-established as an optimal treatment strategy for early-stage BC $[2,11,50,51]$. This may be an overtreatment if RT is imposed on any patient after BCS. Recurrence risk in a considerable proportion of patients is sufficiently low, especially DCIS diagnosed through screening of healthy women [52]. In contrast, for patients with high recurrence risk where only RT may be insufficient, AST (HT and/or CT) should also be administered after BCS [30]. In our meta-analysis, 16 enrolled studies display extreme difference in rates for RT ( $0 \%$ to $100 \%)$, HT ( $0 \%$ to $77 \%$ ), and CT ( $0 \%$ to $66.4 \%$ ) based on the diversity of patient age, pathological types, clinical

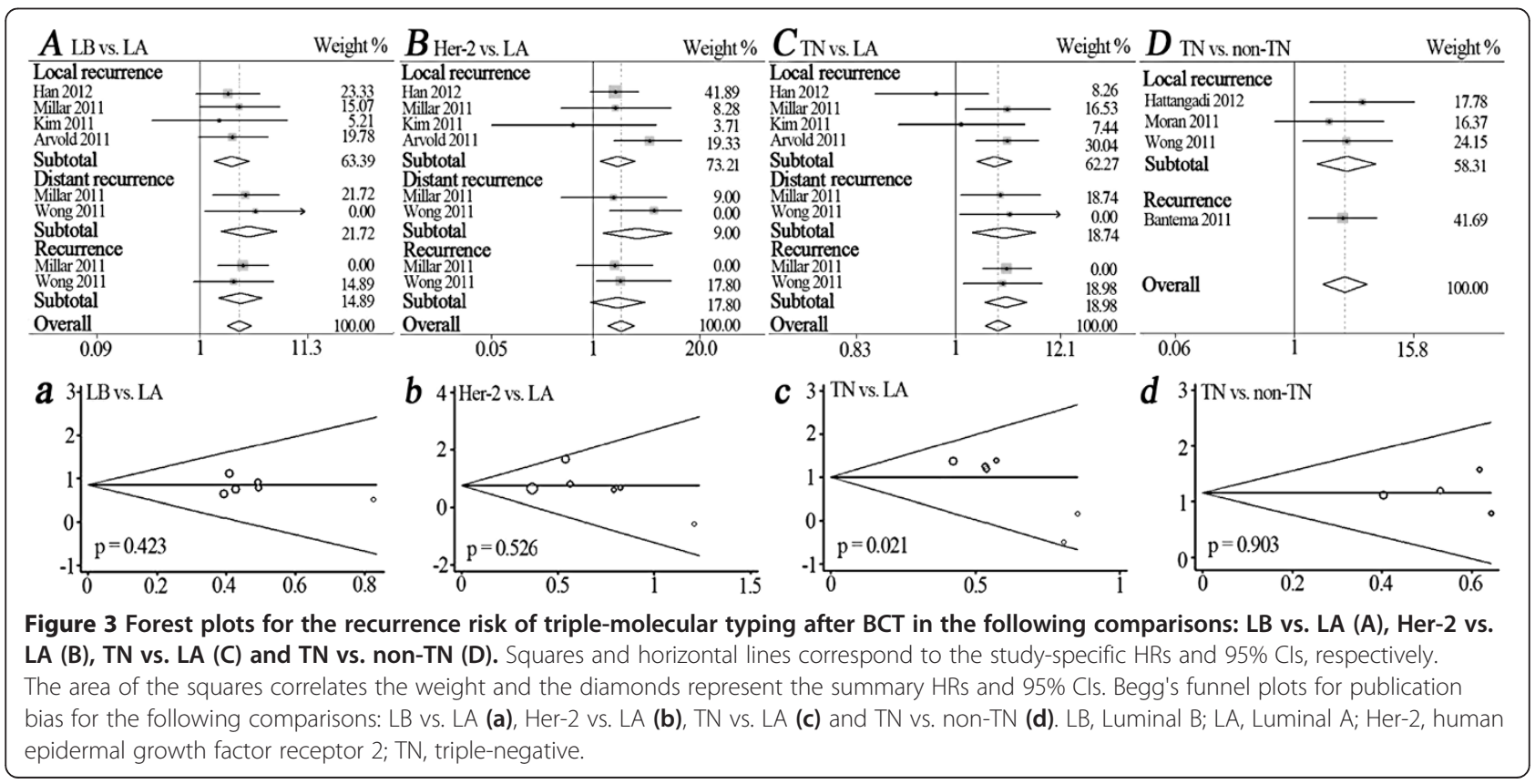


Table 4 Pooled HRs, 95\% Cls, and P values of different dichotomous status of ER, PR, and Her-2 protein stratified by recurrence types

\begin{tabular}{|c|c|c|c|c|c|c|c|c|c|c|c|c|}
\hline \multirow{2}{*}{$\begin{array}{l}\text { Types of } \\
\text { recurrence }\end{array}$} & \multicolumn{3}{|c|}{ LB vs. LA } & \multicolumn{3}{|c|}{ Her-2 vs. LA } & \multicolumn{3}{|c|}{ TN vs. LA } & \multicolumn{3}{|c|}{ TN vs. non-TN } \\
\hline & $\mathrm{N}$ & HR $(95 \% \mathrm{Cl})$ & $P$ & $\mathrm{~N}$ & HR $(95 \% \mathrm{Cl})$ & $P$ & 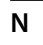 & HR $(95 \% \mathrm{Cl})$ & $P$ & $\mathrm{~N}$ & HR $(95 \% \mathrm{Cl})$ & $P$ \\
\hline Overall & 6 & $2.23(1.55,3.19)^{a}$ & $<0.01$ & 6 & $2.26(1.42,3.60)^{a}$ & 0.001 & 0 & $2.90(1.84,4.58)^{a}$ & $<0.01$ & 4 & $3.19(1.91,5.31)^{a}$ & $<0.01$ \\
\hline Local recurrence & 4 & $2.05(1.31,3.23)^{\mathrm{a}}$ & 0.002 & 4 & $2.33(1.35,4.02)^{\mathrm{a}}$ & 0.002 & 4 & $2.64(1.48,4.71)^{a}$ & 0.001 & 3 & $3.31(1.69,6.45)^{\mathrm{a}}$ & $<0.0$ \\
\hline Distant recurrence & 2 & $3.08(1.62,5.86)^{\mathrm{a}}$ & 0.001 & 2 & $3.64(1.33,9.97)^{a}$ & 0.012 & 2 & $3.60(1.57,8.25)^{a}$ & 0.002 & 0 & - & - \\
\hline Recurrence & 2 & $2.54(1.54,4.19)^{\mathrm{a}}$ & $<0.01$ & 2 & $2.04(0.93,4.49)^{a}$ & 0.075 & 2 & $3.77(2.17,6.55)^{a}$ & $<0.01$ & 1 & $3.03(1.37,6.67)$ & - \\
\hline
\end{tabular}

Local recurrence is defined to include true recurrence (TR), local failure (LF), local recurrence or relapse (LR), ipsilateral breast tumor recurrence (IBTR), locoregional recurrence (LRR), or second ipsilateral breast cancer (SIBC). Distant recurrence is defined to include distant metastasis (DM) or distant failure (DF). Recurrence is defined to include any local and/or distant recurrence, which is the merge of LR and DR in the same study or not definitely mentioned.

${ }^{a}$ The HRs and $95 \% \mathrm{Cls}$ of enrolled studies are pooled by the fixed-effects model.

$\mathrm{Cl}$, confidence interval; Her-2, human epidermal growth factor receptor 2; HR, hazard ratio; LA, Luminal A; LB, Luminal B; N, number of studies; TN, triple-negative.

stages, and surgical margin (Table 1). Therefore, definite evaluation criteria are needed to identify patients at high recurrence risk from those at low risk, and to help choose a more precise postoperative treatment strategy for patients undergoing BCS.

Towards this goal, consideration must be given to the combination of underlying pathological and clinical characteristics. Recent studies have shown that molecular subtypes are prognostic for LR and DR after BCS, and immunohistochemical staining is often used to approximately identify these subtypes $[18,19,53]$. In this review, we take both single-molecular and triple-molecular typing into evaluation (Table 2). To our knowledge, this is the first meta-analysis study to comprehensively assess the effect of molecular subtypes on recurrence after BCT.

Our meta-analysis shows that there are significant differences in recurrence risk among various $B C$ subtypes after BCT. First, we analyzed the efficacy of singlemolecular subtypes. Although a slightly increased risk has been found in both ER negative and PR negative patients, there is no significant effect on LR after BCT. Only Her-2 positive patients display a significantly higher risk for local and overall recurrence when compared to Her-2 negative individuals (Table 3). It reveals that Her-2 positive status could be used clinically as an independent prognostic factor of high recurrence risk, and the status of Her-2 is the most important in the combined efficacy of triple-molecular subtypes. In addition, overexpression of $\mathrm{p} 53$ (p53 positive) is presumed to be a surrogate for TP53 mutations, which are associated with higher tumor grade [54]. Our results display that p53 positive patients have a significantly increased risk for overall recurrence and LR when compared to p53 negative (low expression) individuals (Table 3). Thus, p53 positive subtype should also be considered an important, independent prognostic biomarker for indicating high recurrence risk. P53 positive individuals are more necessary to accept adjuvant RT combined with or without AST and will benefit more than those with $\mathrm{p} 53$ negative $\mathrm{BC}$ for preventing postoperative recurrence because p53 positive subtype also predicts better responsiveness to both RT and AST [54]. Apart from the above mentioned four biomarkers, we did not find any other receptor or protein that met our inclusion criteria. Although Ki67 is generally accepted as one of the most important molecules for BC typing and has been studied over a long period of time [55], only one study was found focusing on our subject [33].

Recently, more studies have focused on the combined efficacy of ER, PR, and Her-2 receptors since the 12th St Gallen International Breast Cancer Conference (2011) Expert Panel adopted a new approach to BC classification for therapeutic purposes based on the recognition of intrinsic biological subtypes [55]. Therefore, we also put emphasis on the relationship between triple-molecular subtypes and recurrence risk after BCT. When compared with Luminal A, Luminal B, Her-2, and triple-negative subtypes all show significantly increased risk for both LR and DR. All HR values for overall recurrence based on triplemolecular typing are greater than 2.0, which can identify patients with higher recurrence risk and shows more clinical prediction value than analyses based on singlemolecular typing (Table 4). For example, the HR value of LR (HR = 2.33) derived from triple-molecular comparison between Her-2 and Luminal A subtypes is larger than the $H R$ value of $L R(H R=1.93)$ derived from single-molecular comparison between Her-2 positive and Her-2 negative subtypes. Therefore, we concluded that the clinical application of triple-molecular typing as a biomarker can better distinguish high-risk individuals compared to single-molecular typing.

Moreover, the comparison between triple-negative and non-triple-negative subtypes shows the biggest risk difference for overall recurrence $(H R=3.19)$ and $L R(H R=$ 3.31) among all molecular typing comparisons. When setting Luminal A as a baseline, the HR value of triplenegative subtype $(H R=2.90)$ remains larger than that of Luminal $B(H R=2.23)$ or Her-2 subtypes $(\mathrm{HR}=2.26)$ for overall recurrence (Table 4). Previous studies have shown that triple-negative receptor status is strongly 
associated with poor clinical outcomes [56], and that young women more frequently suffer from triple-negative tumors [57]. Thus, triple-negative subtype should be considered the biggest risk factor for recurrence and adjuvant CT should be administered in BCT.

Some limitations of this meta-analysis should be acknowledged. First, there are only three studies focused on Asians [35,36,42] and none on Africans in this metaanalysis, hindering comprehensive investigation of the association between $\mathrm{BC}$ molecular typing and recurrence risk after BCT. Second, the sample sizes of enrolled researches (from 39 to 8,724) vary widely, and therefore the statistical power or weight of each study is greatly different, inevitably causing bias to varying degrees. Third, the number of original studies focusing on this topic is insufficient, especially studies related to DR risk.

\section{Conclusions}

Our meta-analysis represents a quantified synthesis of all published studies and shows significant differences in recurrence risk among various molecular subtypes after BCT. Her- 2 positive and $\mathrm{p} 53$ positive subtypes can be considered independent prognostic biomarkers for indicating high LR risk, but triple-molecular biomarkers exhibit higher clinical value than single-molecular biomarkers. Moreover, triple-negative subtype shows the biggest risk for overall recurrence and LR among all molecular subtypes and adjuvant CT should be considered in BCT. Considering the insufficient number of original studies, further research with different ethnicities is needed on this topic, especially the intensity of association between molecular typing and DR risk after BCT.

\footnotetext{
Abbreviations

AST: Adjuvant systemic therapy; BC: Breast cancer; BCS: Breast-conserving surgery; BCT: Breast-conserving therapy; Cls: Confidence intervals; CT: Chemotherapy; DR: Distant recurrence; ER: Estrogen receptor; HER-2: Human epidermal growth factor receptor 2; HR: Hazard ratio; HT: Hormone/endocrine therapy; I2: I-squared statistic; LR: Local recurrence; PR: Progesterone receptor; RT: Adjuvant radiotherapy.
}

\section{Competing interests}

The authors declare that they have no conflict of interest.

\section{Authors' contributions}

JC, PJ, and SW conceived and designed the study. PJ, J-yZ, and YX collected the data. H-jW contributed to quality assessment. M-hG, BZ, and C-yT performed statistical analyses. JC and $\mathrm{H}-\mathrm{yC}$ drafted and revised the manuscript. All authors read and approved the final version.

\section{Acknowledgements}

We thank Dr. Jie Yang from Department of Urology, First Affiliated Hospital of Nanjing Medical University for his gracious assistance in the data collation and analysis.

\section{Author details}

${ }^{1}$ Department of General Surgery of Breast and Thyroid, Nanjing Hospital Affiliated to Nanjing Medical University, Nanjing, China. ${ }^{2}$ Department of Urology, First Affiliated Hospital of Nanjing Medical University, Nanjing, China. ${ }^{3}$ Department of General Surgery, Nanjing Hospital Affiliated to Nanjing
Medical University, Nanjing, China. ${ }^{4}$ Department of Breast Surgery, First Affiliated Hospital of Nanjing Medical University, Nanjing, China.

Received: 21 February 2014 Accepted: 4 July 2014

Published: 15 July 2014

\section{References}

1. Bartelink $H$, Horiot JC, Poortmans PM, Struikmans H, Van den Bogaert W, Fourquet A, Jager JJ, Hoogenraad WJ, Oei SB, Wárlám-Rodenhuis CC, Pierart $M$, Collette $L$ : Impact of a higher radiation dose on local control and survival in breast-conserving therapy of early breast cancer: 10-year results of the randomized boost versus no boost EORTC 22881-10882 trial. J Clin Oncol 2007, 25:3259-3265.

2. Clark RM, Whelan T, Levine M, Roberts R, Willan A, McCulloch P, Lipa M, Wilkinson $\mathrm{RH}$, Mahoney LJ: Randomized clinical trial of breast irradiation following lumpectomy and axillary dissection for node-negative breast cancer: an update. J Natl Cancer Inst 1996, 88:1659-1664.

3. Fisher B, Anderson S, Bryant J, Margolese RG, Deutsch M, Fisher ER, Jeong $\mathrm{JH}$, Wolmark N: Twenty-year follow-up of randomized trial comparing total mastectomy, lumpectomy, and lumpectomy plus irradiation for the treatment of invasive breast cancer. N Engl J Med 2002, 347:1233-1241.

4. Freedman GM, Anderson PR, Hanlon AL, Eisenberg DF, Nicolaou N: Pattern of local recurrence after conservative surgery and whole-breast irradiation. Int J Radiat Oncol Biol Phys 2005, 61:1328-1336.

5. Anderson SJ, Wapnir I, Dignam JJ, Fisher B, Mamounas EP, Jeong JH, Geyer CE Jr, Wickerham DL, Costantino JP, Wolmark N: Prognosis after ipsilateral breast tumor recurrence and locoregional recurrences in patients treated by breast-conserving therapy in five National Surgical Adjuvant Breast and Bowel Project protocols of node-negative breast cancer. J Clin Oncol 2009, 27:2466-2473.

6. Veronesi U, Marubini E, Del Vecchio M, Manzari A, Andreola S, Greco M, Luini A, Merson M, Saccozzi R, Rilke F: Local recurrences and distant metastases after conservative breast cancer treatments: partly independent events. J Nat/ Cancer Inst 1995, 87:19-27.

7. Veronesi U, Cascinelli N, Mariani L, Greco M, Saccozzi R, Luini A, Aguilar M, Marubini E: Twenty year follow-up of a randomized study comparing breastconserving surgery with radical mastectomy for early breast cancer. N Engl J Med 2002, 347:1227-1232.

8. Jacobson JA, Danforth DN, Cowan KH, d'Angelo T, Steinberg SM, Pierce L, Lippman ME, Lichter AS, Glatstein E, Okunieff P: Ten-year results of a comparison of conservation with mastectomy in the treatment of stage I and II breast cancer. N Engl J Med 1995, 332:907-911.

9. Blichert-Toft M, Rose C, Andersen JA, Overgaard M, Axelsson CK, Andersen KW, Mouridsen HT: Danish randomized trial comparing breast conservation therapy with mastectomy: Six years of life-table analysis-Danish Breast Cancer Cooperative Group. J Nat/ Cancer Inst Monogr 1992, 11:19-25.

10. van Dongen JA, Voogd AC, Fentiman IS, Legrand C, Sylvester RJ, Tong D, van der Schueren E, Helle PA, van Zijl K, Bartelink H: Long-term results of a randomized trial comparing breast-conserving therapy with mastectomy: European Organization for Research and Treatment of Cancer 10801 trial. J Natl Cancer Inst 2000, 92(14):1143-1150.

11. Fisher B, Bryant J, Dignam JJ, Wickerham DL, Mamounas EP, Fisher ER, Margolese RG, Nesbitt L, Paik S, Pisansky TM, Wolmark N: Tamoxifen, radiation therapy, or both for prevention of ipsilateral breast tumor recurrence after lumpectomy in women with invasive breast cancers of one centimeter or less. J Clin Oncol 2002, 20:4141-4149.

12. Perou CM, Sørlie $T$, Eisen MB, van de Rijn M, Jeffrey SS, Rees CA, Pollack JR, Ross DT, Johnsen H, Akslen LA, Fluge O, Pergamenschikov A, Williams C, Zhu SX, Lønning PE, Børresen-Dale AL, Brown PO, Botstein D: Molecular portraits of human breast tumours. Nature 2000, 406:747-752.

13. Konecny GE: Impact of molecular breast cancer portraits on new treatment strategies for gynecologic malignancies. Curr Opin Obstet Gynecol 2013, 25(1):38-39.

14. Sørlie T, Perou CM, Tibshirani R, Aas T, Geisler S, Johnsen H, Hastie T, Eisen MB, van de Rijn M, Jeffrey SS, Thorsen T, Quist H, Matese JC, Brown PO, Botstein D, Lønning PE, Børresen-Dale AL: Gene expression patterns of breast carcinomas distinguish tumor subclasses with clinical implications. Proc Natl Acad Sci U S A 2001, 98:10869-10874.

15. Oh DS, Troester MA, Usary J, Hu Z, He X, Fan C, Wu J, Carey LA, Perou CM: Estrogenregulated genes predict survival in hormone receptorpositive breast cancers. J Clin Oncol 2006, 24:1656-1664. 
16. Rouzier R, Perou CM, Symmans WF, Ibrahim N, Cristofanilli M, Anderson K, Hess KR, Stec J, Ayers M, Wagner P, Morandi P, Fan C, Rabiul I, Ross JS, Hortobagyi GN, Pusztai L: Breast cancer molecular subtypes respond differently to preoperative chemotherapy. Clin Cancer Res 2005, 11:5678-5685

17. Nguyen PL, Taghian AG, Katz MS, Niemierko A, Abi Raad RF, Boon WL, Bellon JR, Wong JS, Smith BL, Harris JR: Breast cancer subtype approximated by estrogen receptor, progesterone receptor, and HER-2 is associated with local and distant recurrence after breast conserving therapy. J Clin Oncol 2008, 26:2373-2378.

18. Albert JM, Gonzalez-Angulo AM, Guray M, Sahin A, Strom EA, Tereffe W, Woodward WA, Tucker SL, Hunt KK, Hortobagyi GN, Buchholz TA: Estrogen/ progesterone receptor negativity and HER2 positivity predict locoregional recurrence in patients with T1a, bN0 breast cancer. Int J Radiat Oncol Biol Phys 2010, 77:1296-1302.

19. Voduc KD, Cheang MCU, Tyldesley S, Gelmon K, Nielsen TO, Kennecke H: Breast cancer subtypes and the risk of local and regional relapse. J Clin Oncol 2010, 28:1684-1691.

20. Tang P, Skinner KA, Hicks DG: Molecular classification of breast carcinomas by immunohistochemical analysis: Are we ready? Diagn Mol Pathol 2009, 18:125-132.

21. Tamaki K, Ishida T, Miyashita M, Amari M, Mori N, Ohuchi N, Tamaki N, Sasano H: Multidetector row helical computed tomography for invasive ductal carcinoma of the breast: correlation between radiological findings and the corresponding biological characteristics of patients. Cancer Sci 2012, 103:67-72

22. Tamaki K, Sasano H, Ishida T, Miyashita M, Takeda M, Amari M, Tamaki N, Ohuchi N: The comparison of core needle biopsy (CNB) and surgical specimens for accurate preoperative evaluation of ER, PgR and HER2 status of breast cancer patients. Cancer Sci 2010, 101:2074-2079.

23. Tamaki K, Ishida T, Miyashita M, Amari M, Ohuchi N, Tamaki N, Sasano H: Correlation between mammographic findings and corresponding histopathology: potential predictors for biological characteristics of breast diseases. Cancer Sci 2011, 102:2179-2185.

24. Stroup DF, Berlin JA, Morton SC, Olkin I, Williamson GD, Rennie D, Moher D, Becker BJ, Sipe TA, Thacker SB: Meta-analysis of observational studies in epidemiology: aproposal for reporting. Meta-analysis Of Observational Studies in Epidemiology (MOOSE) group. JAMA 2000, 283:2008-2012.

25. Tierney JF, Stewart LA, Ghersi D, Burdett S, Sydes MR: Practical methods for incorporating summary time-to-event data into metaanalysis. Trials 2007, 8:16.

26. Parmar MK, Torri V, Stewart L: Extracting summary statistics to perform meta-analyses of the published literature for survival endpoints. Stat Med 1998, 17:2815-2834.

27. Williamson PR, Smith CT, Hutton JL, Marson AG: Aggregate data metaanalysis with time-to-event outcomes. Stat Med 2002, 21:3337-3351.

28. DerSimonian R, Laird N: Meta-analysis in clinical trials. Control Clin Trials 1986, 7:177-188

29. Egger M, Smith GD, Schneider M, Minder C: Bias in meta-analysis detected by a simple, graphical test. BMJ 1997, 315:629-634.

30. Hattangadi-Gluth JA, Wo JY, Nguyen PL, Abi Raad RF, Sreedhara M, Niemierko A, Freer PE, Georgian-Smith D, Bellon JR, Wong JS, Smith BL, Harris JR, Taghian AG: Basal subtype of invasive breast cancer is associated with a higher risk of true recurrence after conventionalbreastconserving therapy. Int J Radiat Oncol Biol Phys 2012, 82:1185-1191.

31. Zauls AJ, Watkins JM, Wahlquist AE, Brackett NC 3rd, Aguero EG, Baker MK, Jenrette JM, Garrett-Mayer E, Harper JL: Outcomes in women treated with MammoSite brachytherapy or whole breast irradiation stratified by ASTRO Accelerated Partial Breast Irradiation Consensus Statement Groups. Int J Radiat Oncol Biol Phys 2012, 82:21-29.

32. Han K, Nofech-Mozes S, Narod S, Hanna W, Vesprini D, Saskin R, Taylor C, Kong I, Paszat L, Rakovitch E: Expression of HER2neu in ductal carcinoma in situ is associated with local recurrence. Clin Oncol (R Coll Radiol) 2012, 24:183-189.

33. Millar EK, Graham PH, McNeil CM, Browne L, O'Toole SA, Boulghourjian A, Kearsley JH, Papadatos G, Delaney G, Fox C, Nasser E, Capp A, Sutherland RL: Prediction of outcome of early ER+ breast cancer is improved using a biomarker panel, which includes Ki-67 and p53. Breast Cancer Res Treat 2012, 134:683-692

34. Moran MS, Yang Q, Goyal S, Harris L, Chung G, Haffty BG: Evaluation of vascular endothelial growth factor as a prognostic marker for local relapse in early-stage breastcancer patients treated with breast-conserving therapy. Int J Radiat Oncol Biol Phys 2011, 81:1236-1243.

35. Wong FY, Chin FK, Lee KA, Soong YL, Chua ET: Hormone receptors and HER-2 status as surrogates for breast cancer molecular subtypes prognosticate for disease control in node negative Asian patients treated with breast conservation therapy. Ann Acad Med Singapore 2011, 40:90-96.

36. Kim HJ, Han W, Yi OV, Shin HC, Ahn SK, Koh BS, Moon HG, You JH, Son BH, Ahn SH, Noh DY: Young age is associated with ipsilateral breast tumor recurrence after breast conserving surgery and radiation therapy in patients with HER2-positive/ER-negative subtype. Breast Cancer Res Treat 2011, 130:499-505

37. Bantema-Joppe EJ, van der Laan HP, de Bock GH, Wijsman R, Dolsma W, Busz DM, Langendijk JA, Maduro JH: Three-dimensional conformal hypofractionated simultaneous integrated boost in breast conserving therapy: results on local control and survival. Radiother Oncol 2011, 100:215-220.

38. Arvold ND, Taghian AG, Niemierko A, Abi Raad RF, Sreedhara M, Nguyen PL, Bellon JR, Wong JS, Smith BL, Harris JR: Age, breast cancer subtype approximation, and local recurrence after breast-conserving therapy. J Clin Oncol 2011, 29:3885-3891.

39. Truong PT, Jones SO, Kader HA, Wai ES, Speers CH, Alexander AS, Olivotto IA: Patients with $\mathrm{t} 1$ to $\mathrm{t} 2$ breast cancer with one to three positive nodes have higher local and regional recurrence risks compared with node-negative patients after breast-conserving surgery and whole-breast radiotherapy. Int J Radiat Oncol Biol Phys 2009, 73:357-364.

40. Nofech-Mozes S, Spayne J, Rakovitch E, Kahn HJ, Seth A, Pignol JP, Lickley L, Paszat $L$, Hanna W: Biological markers predictive of invasive recurrence in DCIS. Clin Med Oncol 2008, 2:7-18

41. de Roos MA, van der Vegt B, Peterse JL, Patriarca C, de Vries J, de Bock GH, Wesseling J: The expression pattern of MUC1 (EMA) is related to tumour characteristics and clinical outcome in 'pure' ductal carcinoma in situ of the breast. Histopathology 2007, 51:227-238

42. Yau TK, Soong IS, Chan K, Chan M, Cheung P, Lau HW, Chang AT, Lee AW: Clinical outcome of breast conservation therapy for breast cancer in Hong Kong: prognostic impact of ipsilateral breast tumor recurrence and 2005 St. Gallen risk categories. Int J Radiat Oncol Biol Phys 2007, 68:667-672.

43. Smith BD, Gross CP, Smith GL, Galusha DH, Bekelman JE, Haffty BG: Effectiveness of radiation therapy for older women with early breast cancer. J Natl Cancer Inst 2006, 98:681-690.

44. Silvestrini R, Veneroni S, Benini E, Daidone MG, Luisi A, Leutner M, Maucione A, Kenda R, Zucali R, Veronesi U: Expression of p53, glutathione S-transferase-pi, and $\mathrm{Bcl}-2$ proteins and benefit from adjuvant radiotherapy inbreast cancer. J Natl Cancer Inst 1997, 89:639-645.

45. Brenton JD, Carey LA, Ahmed AA, Caldas C: Molecular classification and molecular forecasting of breast cancer: ready for clinical application? J Clin Oncol 2005, 23:7350-7360.

46. Althuis MD, Dozier JM, Anderson WF, Devesa SS, Brinton LA: Global trends in breast cancer incidence and mortality 1973-1997. Int J Epidemiol 2005, 34:405-412.

47. Ferlay J, Shin HR, Bray F, Forman D, Mathers C, Parkin DM: Estimates of worldwide burden of cancer in 2008: GLOBOCAN 2008. Int J Cancer 2010, 127:2893-2917.

48. Hou N, Huo D: A trend analysis of breast cancer incidence rates in the United States from 2000 to 2009 shows a recent increase. Breast Cancer Res Treat 2013, 138:633-641.

49. No authors listed: Advanced breast cancers increasing in young women. BMJ 2013, 346:f1234

50. Forrest AP, Stewart HJ, Everington D, Prescott RJ, McArdle CS, Harnett AN, Smith DC, George WD: Randomised controlled trial of conservation therapy for breast cancer: 6-years analysis of the Scottish trial. Lancet 1996, 348:708-713.

51. Liljegren G, Holmberg L, Bergh J, Lindgren A, Tabár L, Nordgren H, Adami HO: 10-year results after sector resection with or without postoperative radiotherapy for stage I breast cancer: A randomized trial. J Clin Oncol 1999, 17:2326-2333.

52. White J: Do we need to irradiate all small invasive breast cancers and DCIS? Am Soc Clin Oncol Educ Book 2013, 2013:40-44.

53. Wo JY, Taghian AG, Nguyen PL, Raad RA, Sreedhara M, Bellon JR, Wong JS, Gadd MA, Smith BL, Harris JR: The association between biological subtype 
and isolated regional nodal failure after breast-conserving therapy. Int $\mathrm{J}$ Radiat Oncol Biol Phys 2010, 77:188-196.

54. Thompson AM, Lane DP: p53 transcriptional pathways in breast cancer: the good, the bad and the complex. J Pathol 2010, 220:401-403.

55. Goldhirsch A, Wood WC, Coates AS, Gelber RD, Thürlimann B, Senn HJ, Panel members: Strategies for subtypes-dealing with the diversity of breast cancer: highlights of the St. Gallen International Expert Consensus on the Primary Therapy of Early Breast Cancer 2011. Ann Oncol 2011, 22:1736-1747.

56. Bauer KR, Brown M, Cress RD, Parise CA, Caggiano V: Descriptive analysis of estrogen receptor (ER)-negative, progesterone receptor (PR)-negative, and HER2-negative invasive breast cancer, the so-called triple-negative phenotype: a population-based study from the California cancer Registry. Cancer 2007, 109:1721-1728.

57. Andreu FJ: Histologic diagnosis in young women with breast cancer. Breast Cancer Res Treat 2010, 123:15-18.

doi:10.1186/1477-7819-12-212

Cite this article as: Chen et al:: The efficacy of molecular subtyping in predicting postoperative recurrence in breast-conserving therapy: a 15-study meta-analysis. World Journal of Surgical Oncology 2014 12:212.

\section{Submit your next manuscript to BioMed Central and take full advantage of:}

- Convenient online submission

- Thorough peer review

- No space constraints or color figure charges

- Immediate publication on acceptance

- Inclusion in PubMed, CAS, Scopus and Google Scholar

- Research which is freely available for redistribution 